\title{
PREPARATION AND CHARACTERIZATION OF ANTIBACTERIAL FILMBASED ON CARBOXYMETHYLCELLULOSE FROM GEBANG LEAF (Coryphautan), POLYVINYL ALCOHOL ANDCITRIC ACID
}

\author{
F.K. Siregar ${ }^{1, *}$, D.Y. Nasution ${ }^{2}$ Y. Muis ${ }^{2}$ and D.Y. Kaban ${ }^{1}$ \\ ${ }^{1}$ Post-Graduate School-Chemistry Department, Faculty of Sciences and Mathematics, University \\ of Sumatera Utara,Jl. Bioteknologi No.1, \\ Padang Bulan, Medan Baru, Medan, Indonesia (20155) \\ ${ }^{2}$ Chemistry Department, Faculty of Sciences and Mathematics, University of Sumatera Utara,Jl. \\ Bioteknologi No.1, Padang Bulan, Medan Baru, Medan, Indonesia (20155) \\ *E-mail : fatimahkhaeranisiregar@gmail.com
}

\begin{abstract}
Cellulose extracted from gebang (Corypha utan) leaves was characterized and used as a raw material for preparation of carboxymethyl cellulose which further used for preparing a film. Carboxymethyl Cellulose/polyvinyl alcohol films were prepared by the crosslinking method. The films were chemically crosslinked with citric acid for tuning their properties.The results indicate that the hydrogen bond interactions between carboxymethylcellulose/polyvinyl alcohol and citric acid can be formed. The films demonstrated excellent antibacterial effects against Escherichiacoli and Staphylococcusaureus. Increase the addition of citric acid can efficiently reduce the water absorption of the films. Moreover, the films present three-dimensional structure, porous networks and low toxicity. Therefore, the developed carboxymethyl cellulose/polyvinyl alcohol/citric acid film can be well-suited for biomedical application. Keywords:Gebang,Carboxymethyl Cellulose, Polyvinyl Alcohol, Citric Acid, CrosslinkingMethod
\end{abstract}

(c) RASĀYAN. All rights reserved

\section{INTRODUCTION}

The largest and outermost organ covering the entire body that plays like a protective barrier against external insults is the $\operatorname{skin}^{1}$.it is also concerned in immunological monitoring, vitamin D3 synthesis, protection of organisms against toxins and microorganisms, regulating body temperature, supporting blood vessels and nerves, and preventing dehydration of the body ${ }^{3}$. However, its structure and function performed by complex organs can be influenced by severe injuries ${ }^{4}$.Ineffectivetreatment will facilitate bacterial contamination andposses difficulty to form as well as further trigger skin infections ${ }^{5}$.In the early stages of the infection, the main involved organisms are gram-positive bacteria such as Staphylococcus aureus and Streptococcus pyogenes, while Escherichia coli and Pseudomonas aeruginosaas gramnegative bacteria are just obtained in the final phase during developed chronic wounds ${ }^{8}$.

The most common types of infections are skin and soft tissue infections (SSTIs). In uncomplicated SSTIs, skin exhibits good self-regenerative ${ }^{9}$. However, Complicated SSTIs extending to subcutaneous tissue, fascia, or muscle ${ }^{10}$ require complex treatment combining carefullyselective antimicrobial.In order to the rapid healing process, promising wound dressingmaterial whichis able tohinder both the penetration of bacteria and the growth of microorganisms is needed. Recently, researchers have developed modern polymer film-based biomaterials derived from various natural and synthetic biodegradable materials. The combination of both polymers loaded with antimicrobial drugs is often preferred.

Polyvinyl alcohol(PVA), the biodegradable synthetic polymer,has easy and excellent film-forming properties due to its good solubility, non-toxic and biocompatible properties ${ }^{12}$.

Rasayan J. Chem., 12(2), 554-564(2019)

http://dx.doi.org/10.31788/RJC.2019.1225126

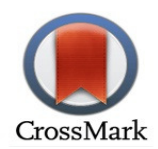


PVA has been applied in several advanced biomedical practices such as injectable bone substitute ${ }^{2}$, biocomposite films ${ }^{6}$, drug delivery,artificial organs and contact lenses ${ }^{11}$. The polymeric material combined with PVA is to improve the mechanical and physicochemical properties of the material ${ }^{12}$.

Carboxymethyl cellulose (CMC), a natural polyelectrolyte polymer,iscapable to absorb a certain amount of water and can retain moisture ${ }^{13}$. Due to its sensitivity to variations in $\mathrm{pH}$ and ionic strength, $\mathrm{CMC}$ is also called a "smart" cellulose derivative ${ }^{13}$. CMC has electrostatic charges connected to the network, thus having a double effect on swelling power capability ${ }^{13}$. In addition, CMC has many advantages such as water-soluble, easily degraded, a good degree of substitution (DS) and low viscosity ${ }^{14}$. CMC is one cellulose ether derivative with carboxymethyl $\left(-\mathrm{CH}_{2} \mathrm{COOH}\right)$ substituents ${ }^{15}$. Substitution of carboxymethyl groups to hydroxyl groups is more dominant in the $\mathrm{C}-2$ glucose position ${ }^{16}$. CMC has been widely used in the medical field because it is very good for wound dressing. In order to improve mechanical properties ${ }^{17}$ and possess well-defined chemical structures, $\mathrm{CMC}$ is suitable to be combined with synthetic polymers like PVA.

CMC can be synthesized from various natural cellulose sources such as fibers, plant wastes, bacteria and various sources of plant cellulose. Gebang (Coryphautan) is a wild plant, has a high size, and lives in lowland areas ${ }^{18}$. Belonging to a family of Arecaceae, this palm tree, has a height of $30 \mathrm{~m}$ and age of 25-30 years old ${ }^{18}$. uniquely, gebang only blooms and produces fruit once in a lifetime ${ }^{18}$. The flowers produced are around 3-15 thousand flowers while the fruit produced is around 240,000-355,000 in each tree ${ }^{18}$. Therefore, the Gebang plant is also referred to as The Mount Everest of the Palm World ${ }^{18}$. Despite long growth, the distribution of gebang plants in Indonesia is still extensive and quite large ${ }^{19}$. Gebang has many benefits including Leaf parts as a traditional mat, traditional salak fruit packaging, traditional Indonesiandodol packaging, midrib as adhesive for building materials, gebang fruit as an anti-cancer agent $^{20}$, shipping materials reinforcement ${ }^{21}$ and rubber filler and reinforcement ${ }^{22}$. The obtained Cellulose content of gebang leaves is approximately $64 \%$. The high cellulose content of gebang leaves is very promising to be used as a source of cellulose and its derivatives.

Preparation and mixing of CMC/PVAcanprovide high elasticity and good mechanical properties ${ }^{23}$. Comparison of the exact composition of both polymerscan produce mechanical properties of material similar to human tissue. To overcome long-term structural and mixed mechanical stability, several crosslinking methods have been made, namely physical, chemical and radiation ${ }^{24}$. The manufacture of the film has undergone new developments and techniques, but more chemically crosslinking methods have been chosen because they produce stable hydrogel structures and good swelling properties ${ }^{25}$. Frequently used crosslinker reagents such as glutaraldehyde, epichlorohydrin, boric acid and sodium trimethaphosphate cause health problems due to their toxicity ${ }^{26}$.

Citric acid (CA) has been successfully used as a crosslinking agent for cellulose derivatives because it is non-toxic, easilydegraded, and good environmental ${ }^{7,27}$. CA is one of the poly carboxylicacids and as the primary organic acid in citrus fruits ${ }^{28}$. CA can be produced through glucose fermentation by Aspergillusniger and Yarrowialipolytica fungi ${ }^{28}$. CA has three carboxylic groups which facilitate tissue formation with cellulose and its derivatives, soCA is very well used as a promising crosslinking agent due to biocompatible and economical properties ${ }^{29}$. In addition, CA has powerful antimicrobial properties ${ }^{30}$. $\mathrm{CA}$ is the second most effective acid among several organic acids that can inhibit the growth of S. aureus in the health and food fields ${ }^{31}$. Combination of CA and natural polymers such as chitosan was able to significantly reduce the growth of negative $E$. coli bacteria ${ }^{32}$. Therefore, the addition of CA to CMC/PVA film can play a role as a crosslinking and antibacterial agent.

Synthesis CMC from cellulose pulp extracted from gebang leaf was the aim of the study. Then, Preparation CMC/PVA/CA film was carried out by the chemically crosslinking method. The structure, crosslinking degree and antibacterial properties of the film were also investigated.

\section{EXPERIMENTAL}

Material and Methods

Gebang leaves (Coryphautan) were obtained from North Padang Lawas, North Sumatera Province, Indonesia. Polyvinyl alcohol (PVA) with a 98\% degree of hydrolysis, Sodium Monochloro acetic (NaMCA), monoanhydrate citric acid (CA) were purchased from Merck, Germany. Acetic acid, ethanol, 
methanol, chloric acid, nitrate acid, acetone and other solvents used were of analytical grade and without further purification. Bacterial strains of E. coli and S.aureus were provided from microbiological laboratory at department biology, University of Sumatera Utara.

\section{Isolation and Purification of Cellulose}

Gebangleaves were washed with water and sun-dried for 4 days. its stick was removed from leaf and cut into small pieces about $1 \mathrm{~cm} .75 \mathrm{~g}$ of product was put into beaker glass and soaked in 1 liter of 3,5\% $\mathrm{HNO}_{3}$ and $10 \mathrm{mg} \mathrm{NaNO}$. The mixture was heated and stirred at $90{ }^{\circ} \mathrm{C}$ for $2 \mathrm{~h}$. The obtained dark brown slurry was filtered and washed with water. The dark yellow product was cooked and stirred in $375 \mathrm{ml}$ of $2 \% \mathrm{NaOH}$ and $375 \mathrm{ml}$ of $2 \% \mathrm{Na}_{2} \mathrm{SO}_{3}$ at $50{ }^{\circ} \mathrm{C}$ for 60 minutes. The solid residue was filtrated and cleaned thoroughly with water. The crude cellulose was bleached with $500 \mathrm{ml}$ of $10 \% \mathrm{H}_{2} \mathrm{O}_{2}$ at $60{ }^{0} \mathrm{C}$ for 45 minutes. The filtrate was removed and the residue was rinsed with water. The bleached cellulose was dried at $60{ }^{\circ} \mathrm{C}$. Dried cellulose was grounded with a blender to obtain its powder.

\section{Synthesis of Carboxymethyl Cellulose (CMC) from Cellulose of Gebang Leaf}

$\mathrm{CMC}$ was synthesized according to the optimized condition procedure performed by Golbaghi et al ${ }^{33}$. one gram of obtained cellulose powder was immediately immersedin $20 \mathrm{ml}$ isopropanol. In order to form alkali cellulose, $4 \mathrm{ml}$ of $28.4 \% \mathrm{NaOH}$ solution was dropwisely offered to the solution and stirred for $1.5 \mathrm{~h}$ at $25{ }^{\circ} \mathrm{C}$. Then, $1.14 \mathrm{~g} \mathrm{MCA}$ was dissolved in $20 \mathrm{ml}$ isopropanol and the solution was added gradually to the prior mixture under stirring for $15 \mathrm{~min}$. The temperature of reaction slightly set at $57.85{ }^{\circ} \mathrm{C}$ for the reaction times of $4.01 \mathrm{~h}$. Water from a constant temperature bath, with an approximate $\pm 2{ }^{\circ} \mathrm{C}$ tolerance, was circulated through the jacket of the reaction vessel to hold the temperature constant during the carboxymethylation process. The mixture was filtered and the obtained CMC was poured into $40 \mathrm{ml}$ absolute methanolunder stirring to dissolve byproduct. After a few minutes, pure acetic acid was provided to complete neutralization. Next, the mixture was refined and rinsed four times with $40 \mathrm{ml}$ of $70 \%$ ethanol and continued washing with $40 \mathrm{ml}$ absolute methanol for abolishingunwanted salts. Finally, the CMC was dried by exposing it to the blowing air followed by putting it in the oven at $60{ }^{\circ} \mathrm{C}$ for $12 \mathrm{~h}$.

\section{Preparation of CMC Film}

A CMC hydrogel film was prepared by dissolving $1.8 \mathrm{~g}$ of CMC in $100 \mathrm{ml}$ distilled water under magnetic stirring at room temperature for 30 minutes. Then $0.2 \mathrm{~g}$ PVA was added to CMC solution under stirring. After the mixture was stirred at $50{ }^{\circ} \mathrm{C}$ for $4 \mathrm{~h}$ and complete solubilization was occurred, the crosslinking agent $\mathrm{CA}$ was added under stirring at concentrations of $10 \%$ (CMC/PVA/CA10) and $15 \%$ (CMC/PVA/CA15) $\mathrm{m} / \mathrm{m} \%$ of CMC+PVA polymer and homogenized for 20 minutes. Afterward, $10 \mathrm{ml}$ of the solutions were cast in a petri dish $\left(60 \mathrm{~mm}\right.$ diameter) and allowed to dry at $40 \pm 2{ }^{\circ} \mathrm{C}$ for $24 \mathrm{~h}$ to remove water. In the sequence, the samples were kept at $80 \pm 2{ }^{\circ} \mathrm{C}$ for $24 \mathrm{~h}$ for the crosslinking reaction (slow evaporation method). As a reference, a sample without CA (CMC/CA0) was also prepared and dried following the same thermal treatment.

\section{Yield of CMC production}

In this research, determination of the yield CMC was performed the following equationRachtanapunet $a l^{34}$ :

$$
\text { Yield of CMC }(\%)=\frac{\text { weight of dry CMC }}{\text { Weight of dry cellulose }} \times 100
$$

\section{The degree of Substitution (DS)}

The DS of CMC was introduced by standard test method ${ }^{51} .4 \mathrm{~g}$ of CMC was treated with $75 \mathrm{ml}$ of $95 \%$ ethanol under stirring for $5 \mathrm{~min}$. In order to agitate, $5 \mathrm{ml}$ of $2 \mathrm{M} \mathrm{HNO}_{3}$ was gained to the mixture. The obtained slurry was placed into hotplate for $2 \mathrm{~min}$. Thereafter the solution was taken up and stirred for 10 min. Next, these were filtered and rinsed three times with $80 \%$ ethanol at room temperature. The obtained precipitate was washed with a $50 \mathrm{ml}$ anhydrous methanol. After alcohol was completely removed, the filter was dried at $105{ }^{\circ} \mathrm{C}$ for $3 \mathrm{~h}$ and cooled in a desiccator for $0,5 \mathrm{~h}$. The final dry CMC was added 
with $100 \mathrm{ml}$ of water and $25 \mathrm{ml}$ of $0.3 \mathrm{~N} \mathrm{NaOH}$ solution under stirring. Then, once the solution was hot, it was placed into hotplate to boil for 15-20 min. The last phase, the mixture was treated by titration with $0.3 \mathrm{~N} \mathrm{HCl}$ to a phenolphthalein end point.Finally, The DS of CMC haspresented the following formula:

$$
\begin{array}{ll}
\mathrm{DS} & =\frac{0.162 A}{1-0.058 A} \\
\mathrm{~A} & =\frac{(B C-D E)}{F}
\end{array}
$$

Where:

A: the obtained weight of alkali per gram of sample

$\mathrm{B}$ : the amount of $\mathrm{NaOH}$ solution $(\mathrm{ml})$

C: the normality of $\mathrm{NaOH}$ solution

$\mathrm{D}$ : the amount of $\mathrm{HCl}$ solution $(\mathrm{ml})$

E: the normality of $\mathrm{HCl}$ solution

F: the weight of the sample (gr)

\section{Water Absorption of CMC Films}

The films were divided into $5 \times 5 \mathrm{~mm}^{2}$ samples, dried at $40 \pm 2{ }^{\circ} \mathrm{C}$ and weighted ( $\mathrm{W}_{1}$, initial mass). Then, the film (triplicates, $\mathrm{n}=3$ ) were placed in $70 \mathrm{~mL}$ sample pots with $10 \mathrm{~mL}$ distilled water at RT. After 72 hours, the filmwas removed from the solution, gently wiped with filter paper to remove excess of liquid on the sample surface and weighted $\left(\mathrm{W}_{2}\right)$. Weight measurements obtained in each step of the process were used to calculate the absorption water of the films using Equations below:

$$
\text { Water Absorption }(\%)=\frac{\mathrm{W} 2-\mathrm{W} 1}{\mathrm{~W} 1} \times 100 \%
$$

\section{Degree of Crosslinking}

To determine the degree of crosslinking quantitatively, the content of the filmwas explored. The gel content of the film was evaluated by extraction of the dried film $(\mathrm{Wd})$ in hot distilled water at $100{ }^{\circ} \mathrm{C}$ for $36 \mathrm{~h}$ and dried at $50{ }^{\circ} \mathrm{C}$ for $4 \mathrm{~h}$ until they reached constant weight (We). The gel yield of the filmwas determined as follows :

$$
\text { Gel } \%=\left(\frac{\mathrm{We}}{\mathrm{Wd}}\right) \times 100
$$

\section{Fourier Transform Infrared Spectroscopy (FTIR)}

Fourier Transform Infrared (FTIR) spectra of extracted cellulose, CMC, PVA and CMC film samples were recorded with Shimadzu IR Prestige-21 spectrophotometer. Pellets were made from each sample and $\mathrm{KBr}$ with a ratio of around $0.05(\mathrm{~g} / \mathrm{g})$. Transmission levels were measured at wave number 500-4000 $\mathrm{cm}^{-1}$.

\section{X-Ray Diffractometry (XRD)}

Diffraction diagrams of extracted cellulose, CMC, PVA and CMC film samples were analyzed using Xray diffraction with a Shimadzu XRD-6100 Diffractometer operating at 40kV and $30 \mathrm{~mA}$ with Ni-filtered Cuk $\alpha$ radiation. Diffraction patterns were recorded at a $2 \theta$ range of $7^{0}-70^{\circ}$ with a scan rate of $2^{\circ} / \mathrm{min}$.

\section{Scanning Electron Microscopy (SEM)}

The surface morphologies of films were investigated using a scanning electron microscope CoxemBenchtop EM 30 AX Plus, South Korea. The scanned surfaces of dried resin were coated with a thin gold layer to avoid charging under the electron beam. SEM photographs were taken at different magnification in the range of $50 \times, 100 \times, 250 \times, 500 \times, 1000 \times$ and $2000 \times$. 


\section{Antibacterial Activity}

Antibacterial nature of film having different amounts of CA was determined by test method AATCC 1001998. The antibacterial activity was evaluated by a zone of inhibition and colony count methodagainst gram-positive bacteria, $S$. aureusand gram-negative bacteria, E. coli. In order to evaluate inhibition zone, the colonies of $S$. aureus (ATCC 25923) and E. coli (ATCC 35218) obtained from an overnight culture, were treated in Muller Hinton Broth (MHB) to form suspension and turbidity was set as 0.5 McFarland standards. $200 \mu \mathrm{L}$ of the suspension was placed into Muller Hinton Agar (MHA) plates to produce a semi-confluent growth. The other membranes were located in inoculated medium and the plates were incubated for $24 \mathrm{~h}$ at $37{ }^{\circ} \mathrm{C}$. finally, inhibition zones were observed the next day.

To determine the colony count method, E. coli (ATCC 11105) was for the testing bacterium. $105 \mathrm{CFU} / \mathrm{ml}$ was a Mother culture. In this procedure, the Luria/Nutrient broth solution was producedfrom bacteria inoculation with test and control samples in it in separate containers.

Sterilization was treated in an autoclave for $20 \mathrm{~min}$ at $121{ }^{\circ} \mathrm{C}$ at $15 \mathrm{lb}$ pressure. Containers with nutrient broth, samples and bacteria culture were shaken at $200 \mathrm{rpm}$ at $37{ }^{\circ} \mathrm{C}$ for $24 \mathrm{~h}$. Agar plates were prepared by pouring the required quantity of a sterilized mixture of nutrient/luria agar and agar in the Petri dishes and allowing them to get solidified. After serial dilution, growth liquid was spread on the surface of solidified agar. All the Petri dishes were incubated thereafter at $37{ }^{\circ} \mathrm{C}$ for $24 \mathrm{~h}$. The antimicrobial activity of the film was calculated.

\section{RESULTS AND DISCUSSION \\ The degree of Substitution (DS) and Yield Percentageof CMC}

The yield percentage of cellulose production from dried gebang leaf was found to be $64 \%$. Synthesis CMC was carried out by two stages. these were alkalization andcarboxymethylation using sodium monochloroacetate (NaMCA). The DS values were usually rangedfrom $0.4-1.3^{36}$. The solubility degree of CMC was based on substitution of a carboxymethylgroup in cellulose structure. According to the optimization of CMC production condition reported by Golbaghi et al, the obtained CMC from gebang leaf had the DS of 1.2 and the yield of $166 \%$. Based onSjostrom, OH group of cellulose was substituted by carboxymethyl group in $\mathrm{C} 2$ position of cellulose structure due to higher acidity and dissociation value of $\mathrm{OH}$ group.

\section{Degree of Crosslinking}

The effect of the concentration of CA on the crosslinking percentage is increased. It was found that the percentage crosslinking of CMC/PVA/CA10\% and CMC/PVA/CA15\% is $9 \%$ and $11 \%$, respectively. With an increased concentration of CA, more monomer radicals may be available to interact with CMC macroradicals, which increases the percentage of crosslinking. Ester bonds, as a result of crosslinking reaction, was more potential formed in $\mathrm{C} 6$ position of cellulose chain due to higher reactivity of its $\mathrm{OH}$ group to esterification ${ }^{38}$. A possible reaction of film formation was shown in Fig.-1.

\section{Water Absorption of CMC/PVA/CA Film}

The effects of the concentration of CA on the water absorption of the film prepared from CMC/PVA are examined based on weight. The water absorption of the filmdecreases from $50 \%$ to $35 \%$. The water absorption of film decreased with an increased concentration of CA. This was due to the increased crosslinked density with the increase in the concentration of CA. Therefore, the chain segments of the polymer chain shortened with increased cross-linking of the chain and reduced the water absorption values of the film because limited space was available for free water to enter into the vacant spaces of the cross-linked network ${ }^{39}$.

\section{Fourier Transform Infrared (FTIR) Spectroscopy Analysis}

According to figure 3, the frequency of absorption bands of cellulose and carboxymethyl cellulose were similar. It isindicated that both of them have similaritiesin functional groups. The broad peak at 3300-3450 $\mathrm{cm}^{-1}$ is presented by $\mathrm{O}-\mathrm{H}$ stretching. Saturated aliphatic $\mathrm{C}-\mathrm{H}$ group from cellulose chain appears at 2900$3000 \mathrm{~cm}^{-140}$. The band around $1060 \mathrm{~cm}^{-1}$ is due to C-O-C stretching ${ }^{41}$. In spectra of obtained cellulose, the band around $1635.65 \mathrm{~cm}^{-1}$ is related to $\mathrm{O}-\mathrm{H}$ bond of cellulose structure. However, in spectra of CMC, 
these peaks were completely removed. On the other hand, the new peak at $1604.77 \mathrm{~cm}^{-1}$ is assigned to stretching vibration of the carbonyl group from COO-. It is indicated that the O-H group of cellulose chain is successfully altered by carboxymethyl group ${ }^{42}$. The small peaks detected at $894.97 \mathrm{~cm}^{-1}$ were confirmed to $\beta$ 1-4 glycoside bonds ${ }^{43}$. Absorptions differed from cellulose spectra at 1604.77 and 1419.61 $\mathrm{cm}^{-1}$ are related to $\mathrm{C}=\mathrm{O}$ stretching and $-\mathrm{CH}_{2}$, respectively. Based on Mario et al report, the existence of the carbonyl group and it salt that assigned to carboxymethyl group was observed at $1600-1640 \mathrm{~cm}^{-1}$ and $1400-1450 \mathrm{~cm}^{-1}$. Therefore, this result confirmed that CMC could be synthesized from the cellulose of gebang leaf.

The FTIR spectrum of PVA also presented characteristic broad bands for hydroxyl groups at $3387 \mathrm{~cm}^{-1}$, for the stretching vibration of $\mathrm{C}-\mathrm{H}$ bonds at $2939 \mathrm{~cm}^{-1}$ and for stretching vibration of C-O bonds at 1419 and $1096 \mathrm{~cm}^{-1}$. Other small peaks at $918.12 \mathrm{~cm}^{-1}$ and $848.68 \mathrm{~cm}^{-1}$ are related to the existence of $-\mathrm{OH}$ bonds dan $-\mathrm{CH}$ bending. These bands were previously reported by Silverstein et al ${ }^{44}$.The decrease of the intensity of $\mathrm{OH}$ bands at $3400-3200 \mathrm{~cm}^{-1}$ that related to form hydrogen bond and the reference peaks at approximately $896 \mathrm{~cm}^{-1}$ of $\beta$ 1-4 glycoside bonds were to confirm crosslinked cellulose. FT-IR Spectra of $\mathrm{CMC} / \mathrm{PVA} / \mathrm{CA} 10 \%$ and CMC/PVA/CA15\% films showed that hydroxyl groups of CMC possesseddepletion at approximately $3448.72 \mathrm{~cm}^{-1}$ during the crosslinking reaction. It was happened due to the chemical reaction with citric acid to form ester bonds.In addition, there were new peaks observed at $1720.50 \mathrm{~cm}^{-1}$ and $1205-1230 \mathrm{~cm}^{-1}$.
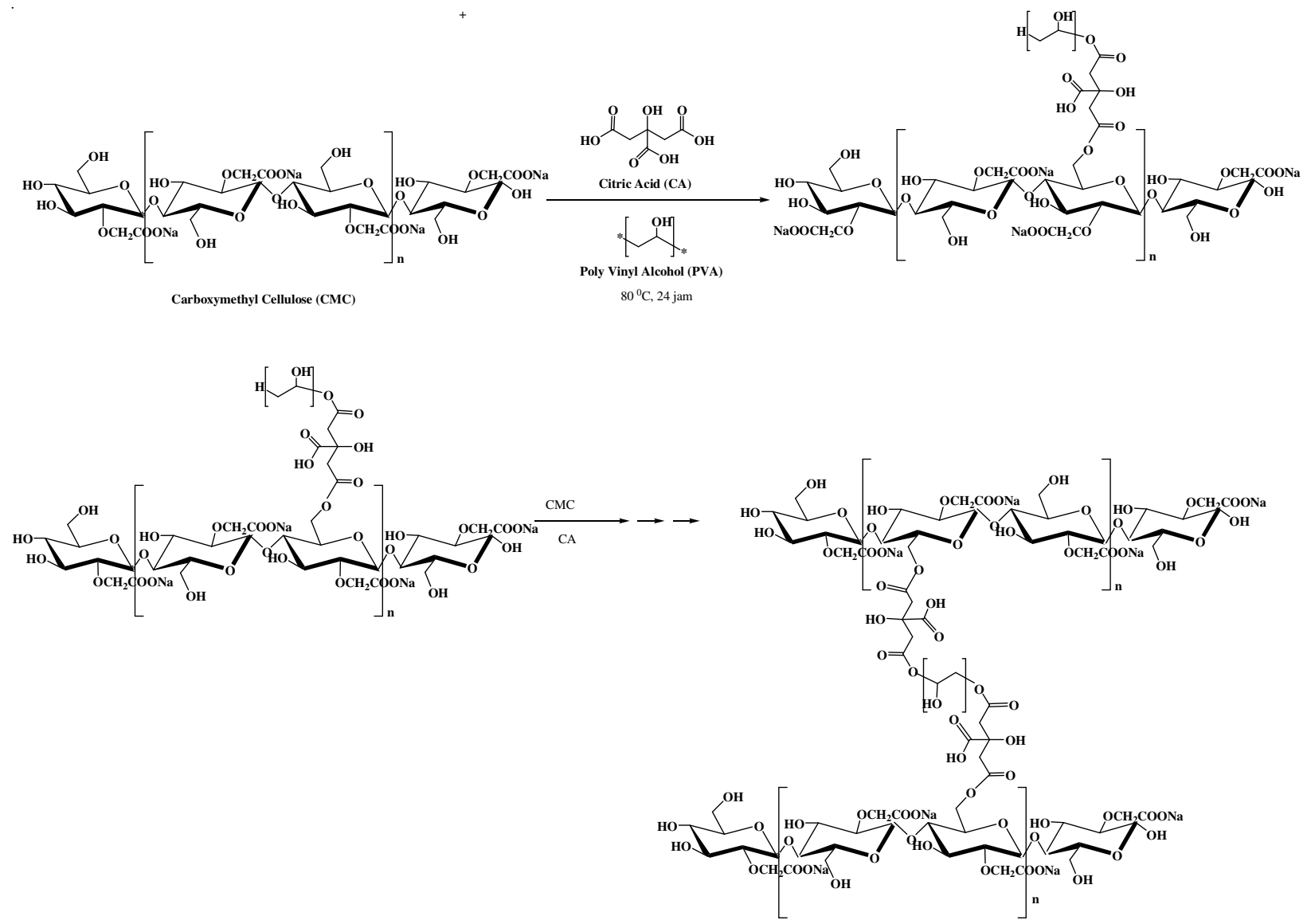

Fig.-1: Possible Reaction for the Formation of CMC/PVA/CA Film (B)

According to Azeredo et $\mathrm{al}^{45}$, these were described to $\mathrm{C}=\mathrm{O}$ and $\mathrm{C}-\mathrm{O}$ of ester bonds formed as a product of the crosslinking reaction. However, the FTIR spectra werecomplicated to evaluatebecause of overlapping with carboxylic bands of $\mathrm{CMC}$, forming different groups in the reaction and $\mathrm{pH}$ effect of the protonation of carboxymethyl groups of $\mathrm{CMC}$ by adding citric acid ( $\mathrm{RCOO} / \mathrm{RCOOH})$. Therefore,thesewere not the main method to describe the crosslinking process. In other words, it was assumed there were other possible interactions overlapped in a similar area. 

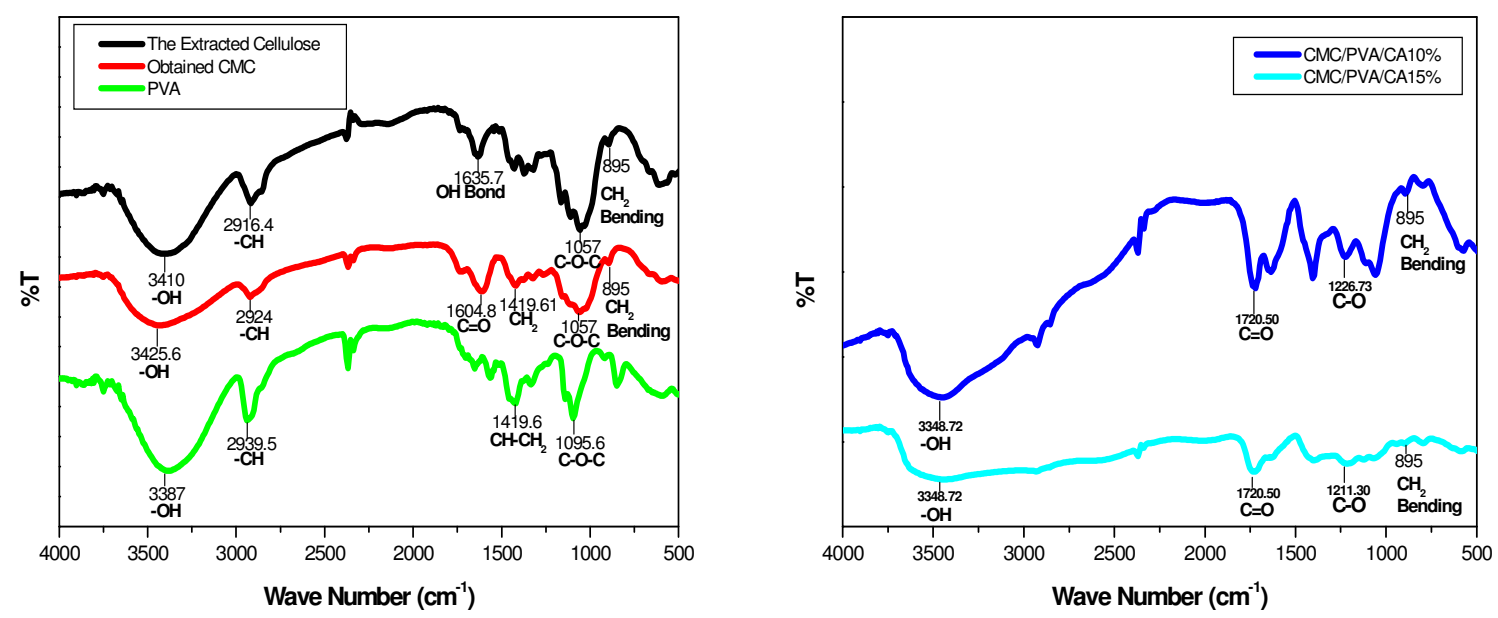

Fig.-2: FT-IR Spectra of Extracted Cellulose, Obtained CMC, PVA, and CMC/PVA/CA Films

\section{X-Ray Diffraction (XRD) Analysis}

Figure-3a shows the X-ray diffraction pattern, in which the typical peak of cellulose and carboxymethylcellulose are observed. The diffraction pattern of cellulose presented two broad and small peaks at $2 \theta$ values of $16.1^{\circ}$ and $2 \theta=22.7^{\circ}$ that are related to the type of cellulose- 1 structure. These peaks were also assigned to amorphous regions. The intense peaks observed around $2 \theta=43.97^{\circ}$ and $64.34^{\circ}$ andthe small oneat $2 \theta=37.72^{\circ}$ corresponded to the crystalline area of cellulose chain. After the carboxymethylation process, these reflection peaks were removed.
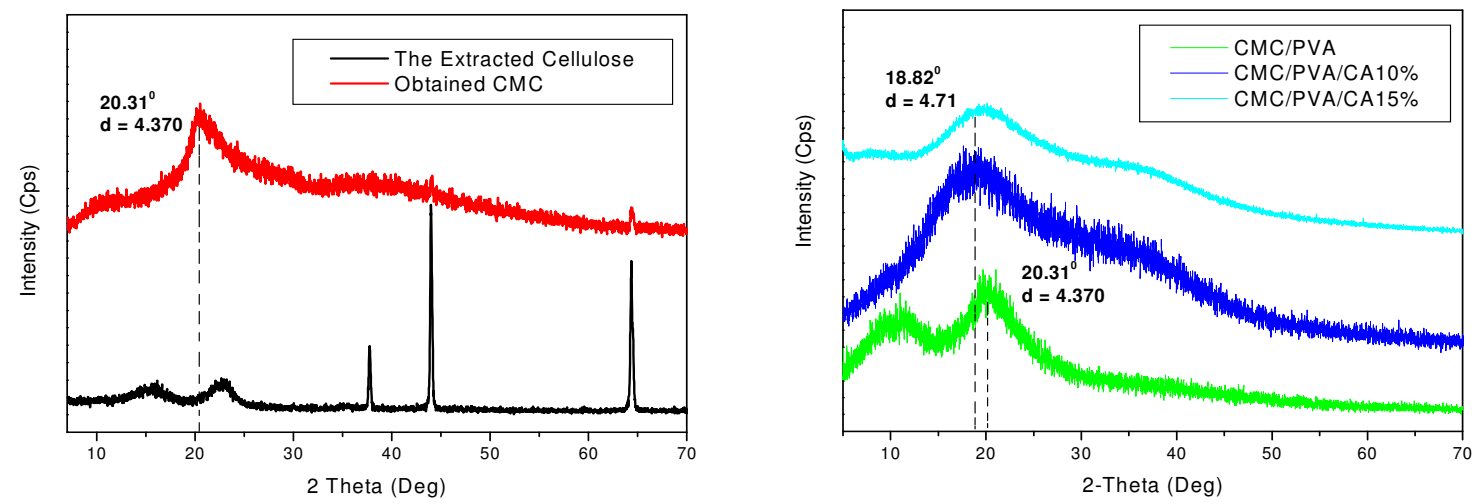

Fig.-3: X-Ray Diffraction Pattern of the Extracted Cellulose, Obtained CMC, CMC/PVA and CMC/PVA/CA Films

In the alkalization process, the addition of $\mathrm{NaOH}$ as swelling agent possessed the crystalline structure of cellulose in CMC spectra destructed. CMC has a maincharacteristic peak at $2 \theta=20.31^{0}$ which described to less crystallin due to the cleavage of hydrogen bonds from $\mathrm{NaOH}^{36}$. In addition, the DS value of obtained CMC was of 1.2. DS value greater than 1 was decreased crystallinity of CMC as reported by Golbaghi et al. Low crystallinity properties were also found in CMC from durian rind $^{34}$. Based on fig. 3, The diffractogram of the CMC/PVA film observed at $2 \theta=20.31^{0}$ is similar to the obtained CMC. It is possibly indicated that hydrogen bonding interaction was still not occurred. Therefore, It is proved that the chemical reaction in the CMC/PVA film was unavailable, but it was only a mixture ${ }^{47}$. While the citric acid (CA) is added the cross-linking occurs and the peak intensity of films have been moved to $18.82^{\circ}$. It could be explained that the crystallinity is decreased while cross-linking occurs between CMC and PVA because of hydrogen bonding interactions. In other words, the use of citric acid as crosslinking agent hindered the folding of polymer chains that resulted crystalline regions in the polymeric network. 


\section{Scanning Electron Microscopy (SEM) Analysis}

In this study, uniformity and microstructural characterizations of films were assessedusing scanning electron microscopy (SEM). The SEM micrographs of CMC/PVA was given in Fig.-4. The figure of CMC/PVA film showed that morphological surface seemed to be less homogenous and smooth. It is possibly proved that both components were difficult to interact due to macromolecule of CMC. While the cross-linker CA content of film increased, crosslinking degree increased and film have more stiff structure. The SEM results showed that these structures have

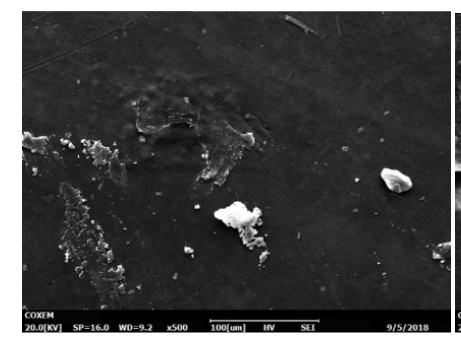

(a)

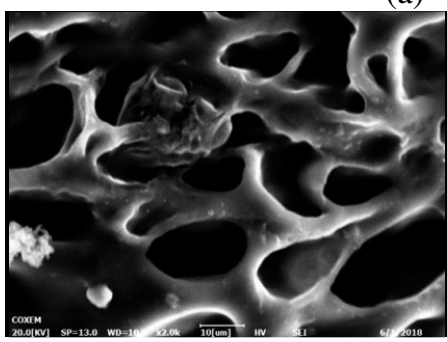

(d)

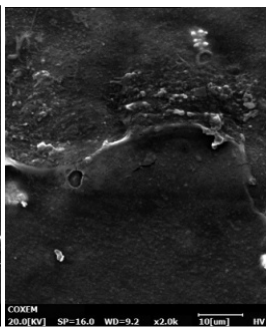

(b)

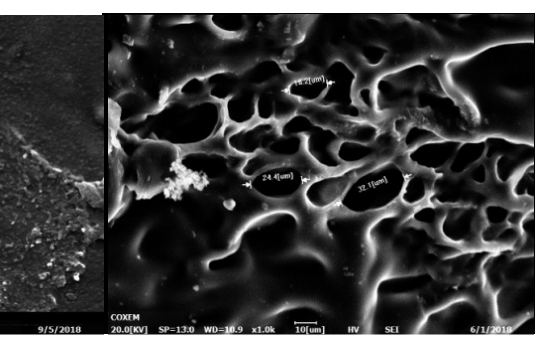

(c)

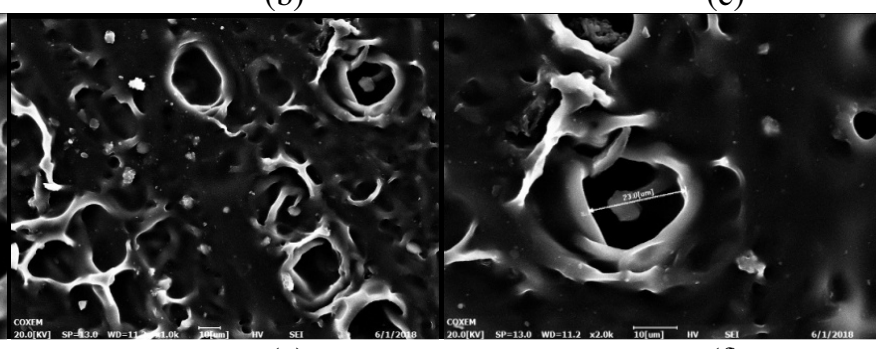

(e)

(f)

Fig.-4: SEM Micrograph of the Morphologies of the Samples (a) CMC/PVA at $500 \mathrm{x}$, (b) CMC/PVA at $2000 \mathrm{x}$, (c)

$\mathrm{CMC} / \mathrm{PVA} / \mathrm{CA} 10 \%$ at $500 \mathrm{x},(\mathrm{d}) \mathrm{CMC} / \mathrm{PVA} / \mathrm{CA} 10 \%$ at $2000 \mathrm{x}$, (e) CMC/PVA/CA15\% at $500 \mathrm{x}$ and (f) $\mathrm{CMC} / \mathrm{PVA} / \mathrm{CA} 15 \%$ at $2000 \mathrm{x}$

three-dimensional network structure.Moreover, CMC/PVA/CA10\% film exhibits more porous,homogenousand good three-dimensional network along with interconnectivity between the poresdue to a less crosslinking percentage. Interconnected pore structure enables the diffusion of water molecules through the pore. Size pores of CMC/PVA/CA10\% and CMC/PVA/CA15\% film were $32 \mu \mathrm{m}$ and $23 \mu \mathrm{m}$, respectively. While CMC/PVA/CA15\% film showed less porous and denser structure. it indicated the large presence of ester-forming. Thus, the ability of film to absorb water was limited.

\section{Antibacterial Activity}

The antibacterial properties of the film were tested using the disk diffusion method. This method is carried out to determine the response of bacterial growth inhibition of compound by measuring the diameter of the clear zone using the calipers. The antimicrobial efficacy of CMC/PVA, CMC/PVA/CA10\% and CMC/PVA/CA15\% films was evaluated against Gram-positive S. aureus and Gram-negative E. coli. Figure 6(a)(b) was presented with the zones of inhibition. There is no zone of inhibition observed around the discs of CMC/PVA containing samples. Since CMC and PVA cannot be released out into the bacterial medium, they cannot observe a zone of inhibition. Antibacterial activity from the test showed that CMC/PVA/CA10\% and CMC/PVA/CA15\% films had the ability to effectively inhibit and kill the growth of both gram-negative (Escherichia coli) and gram-positive (Staphylococcus aureus) bacteria. The inhibitory power of bacteria is getting better with increasing concentration of CA in the film. This can be seen from the results of the antimicrobial index zone of the two film samples in Table-1.

CMC/PVA/CA films have powerful antibacterial properties. This is due to the antimicrobial chemical properties of citric acid in the polymer network. According to the degree of crosslinking and FTIR spectra, CA, as crosslinker agent, did not fully react with both CMC and PVA. In other words, there is still $\mathrm{COOH}$ groups of $\mathrm{CA}$ remained in films. It possibly played a role as undissociated form in 561 
antibacterial activity ${ }^{48}$. Thus, citric acid has an undissociated form which is a molecule that can penetrate the bacterial cell membrane, making it capable of donating hydrogen ions in the system ${ }^{48}$.Citric acid can kill bacteria through the mechanism by which the undissociated molecules $(\mathrm{COOH})$ are able to penetrate the cell membrane of microorganisms and ionize them ${ }^{48}$. To maintain intracellular $\mathrm{pH}, \mathrm{H}^{+}$ions are released, resulting in a weak internal $\mathrm{pH}^{48}$. Acidic conditions in cells cause deformation and damage to enzymatic activity, protein and DNA structure, thus damaging the extracellular membrane ${ }^{48}$. In another mechanism, changes in cell membrane permeability inhibit substrate transport. In addition, changes in $\mathrm{pH}$ in cells suppress the oxidation of NADH which affects the electron transport system and causes the death of microorganisms ${ }^{49}$.

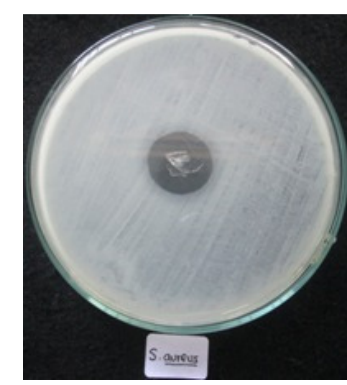

(a) (b)

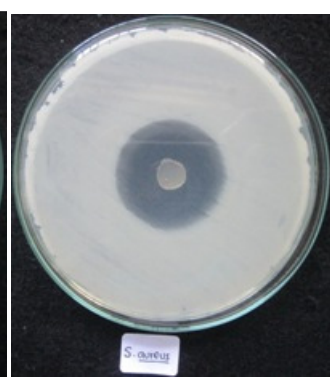

(c)

(d)

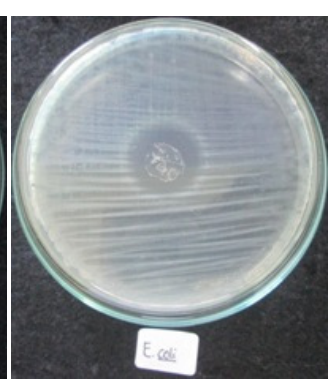

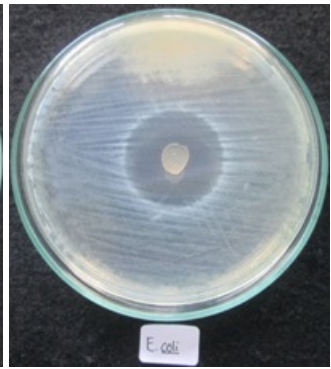

Fig.-5: Antimicrobial Activity of Sampels having (a) CMC/PVA, (b) CMC/PVA/CA10\% (c) CMC/PVA/CA15\% against $S$. aureus and (a) CMC/PVA, (b) CMC/PVA/CA10\% (c) CMC/PVA/CA15\% against $E$. coli by Zone Inhibition Method

Table-1: Antibacterial Inhibition Zone

\begin{tabular}{c|c|c|c|c}
\hline Bacteria & CA Concentration & $\begin{array}{c}\text { Sample Film } \\
\text { Diameter }(\mathrm{mm})\end{array}$ & $\begin{array}{c}\text { Clear Zone } \\
\text { Diameter (mm) }\end{array}$ & $\begin{array}{c}\text { Antimicrobial } \\
\text { Index Zone }\end{array}$ \\
\hline \multirow{2}{*}{ S. aureus } & $10 \%$ & 7 & 16.9 & 1.41 \\
\cline { 2 - 5 } & $15 \%$ & 7 & 29.6 & 3.22 \\
\hline \multirow{2}{*}{ E. coli } & $10 \%$ & 7 & 18.1 & 1.58 \\
\cline { 2 - 5 } & $15 \%$ & 7 & 25.9 & 2.70 \\
\hline
\end{tabular}

CMC/PVA/CA15\% films have a greater index of antimicrobial zones against gram-positive bacteria, namely $S$. Aureus compared to gram-negative bacteria $E$. Coli. This is because these microorganisms do not have an outer membrane which can facilitate antimicrobial agents to enter bacterial cells. Single-layer gram-positive bacterial cell wall structure with low lipid content (1-4\%), whereas gram-negative bacteria have high lipid content $(11-12 \%)$ and the outer membrane consists of 3 layers, namely lipopolysaccharide, lipoprotein, and pospolipid ${ }^{50}$. Thus, gram-positive bacteria such as $S$. aureus are more sensitive to antimicrobial agents.

\section{CONCLUSION}

The result of the characterization of structural analysis on CMC/PVA/CAfilm with FT-IR and XRD analysis indicated CMC/PVA was successfully crosslinked with CA. The percentage of crosslinking increased with the addition of CA was of $9 \%$ and $11 \%$. The use of the crosslinkingreagents CA10\% and $\mathrm{CA} 15 \%$ on the CMC/PVA reduced its water absorption by $50 \%$ and $35 \% \%$, respectively. This resultwas due to the density of the crosslinking formation. The morphological analysis on film with SEM photographs showed that film created micropores and strong 3D polymeric networks. Antibacterial activity of films was examined on E. choli and $S$. aureus based on agar diffusion test. Films showed very good antibacterial activity against both gram-positive and gram-negative bacteria. Therefore, CMC/PVA/CA film could be considered to be a supporting material for different medical applications.

\section{ACKNOWLEDGMENT}

This work was developed with financial support from Mr. Hakimuddin Siregar. The authors are grateful to Mrs Ayu, Basic Chemistry Laboratory and Ms Suci, Physical Chemistry Laboratory, University of 
RASĀYAN J. Chem.

Vol. 12 | No. 2 |554 - 564| April - June | 2019

Sumatera Utara, for providing infrastructure to carry out research work. Sincere thanks are also given to Organic Chemistry Laboratory, Universitas Gajah Mada who supported to analyze FTIR Spectra.

\section{REFERENCES}

1. A.W.C. Chua, Y.C. Khoo, B. K. Tan, K.C. Tan, C.L. Foo andS.J. Chong, Burns \& Traum, 4, 3 (2016), DOI:10.1186/s41038-016-0027-y

2. Firnanelty, S. Sugiarti and Charlena, Rasayan J. Chem., 10(2), 570(2017), DOI: 10.7324/RJC.2017.1021465

3. S. Haberzeth-Bottcher, T. Biedermann, E. Reichmann, Burns, 36(4), 450 (2010), DOI: 10.1016/j.burns.2009.08.016.

4. M. Mühlstädt, C. Thomé, and C. Kunte, British Journal of Dermatology, 167, 343 (2012), DOI: 10.1111/j.1365-2133.2012.10999.x

5. V. Ki and C. Rotstein, Canadian Journal of Infectious Diseases and Medical Microbiology, 19, 17 (2008)

6. G. Nandhavathy, S. P. Selvam, M. M. Kumar and E. R. Sadiku, Rasayan J. Chem., 10(2), 542(2017), DOI: $10.7324 /$ RJC.2017.1021724

7. E.Ramu, V.Kotra, N. Bansal, R.Varala and S. R. Adapa, Rasayan J. Chem., 1(1)188 (2008)

8. A.F. Cardona and S.E. Wilson, Clin Infect Dis, 61, S69 (2015), DOI: 10.1093/cid/civ528

9. M. Sand, T. Gambichler, D. Sand, M. Skrygan, P. Altmeyer, F.G. Bechara, Journal of Dermatological Sciences, 53, 169 (2009), DOI:10.1016/j.jdermsci.2008.10.004

10. May A.K, Surg Infect (Larchmt), 12(3), 179 (2011), DOI:10.1089/sur.2011.034

11. A.K. Elbadawy, X. Chen, M.S.M. Eldin, E.S. Kenawy, Arabian Journal of Chemistry, 8(1), 1(2015), DOI:10.1016/j.arabjc.2014.07.005

12. F.E.F. Silva, M.C.B. Di-Medeiros, K.A. Batista, and K.F. Fernandes, Journal Materials, 1(2013), DOI: $10.1155 / 2013 / 413578$

13. A.Sannino, C. Demitri, and M. Madaghiele, Materials, 2(2), 353(2009), DOI:10.3390/ma2020353

14. F. Jia, H.J. Liu, G.G. Zhang, Procedia Environmental Sciences, 31, 98(2016), DOI: $10.1016 /$ j.proenv.2016.02.013

15. A.Sannino, M. Madaghiele, F. Conversano, G. Mele, A. Maffezzoli, P.A. Netti, L. Ambrosio, L. Nicolais, Biomacromolecules, 5(1), 92 (2004), DOI:10.1021/bm0341881

16. D.Charpentier,G. Mocanu, A. Carpov, S. Chapelle, L. Merle and G. Muller, Carbohydrate Polymers, 32, 177 (1997), DOI:10.1016/S0144-8617(97)00031-3

17. D.Sahoo, S. Sahoo, J. Das, T.K. Dangar, P.L. Nayak, NanoTrends: A Journal of Nanotechnology and Its Applications, 10, 1 (2011), DOI: 10.13140/RG.2.2.10095.74406

18. R.E.Nasution, and H.C. Ong, In: Brink M and RP Escobin (Eds). Fibre plants. Yayasan PROSEA (Plant Resources of South East Asia) Foundation, Bogor, Indonesia, pp 114-117 (2003).

19. R.P.Sancayaningsih, S.H.M.B. Santosa and M.F Maharani, In Conference of International Seminar on New Paradigm and Innovation on Natural Sciences and Its Application (ISNPINSA), Semarang, Indonesia, pp 1-6 (2012).

20. L. Heliawati, A. Kardinan, T. Mayanti1, and R. Tjokronegoro, Journal of Applied Pharmaceutical Science, 5(1), 110 (2015), DOI: 10.7324/JAPS.2015.50119

21. H.B. Setiawan, H. Yudo, and S. Jokosisworo, Jurnal Teknik Perkapalan, 5(2), 1 (2017), https://ejournal3.undip.ac.id/index.php/naval/article/view/16963

22. R.D.Indiah, A. Yuniari, M. Sholeh, N.M. Setyadewi, In proceedings of Prosiding Seminar Nasional Kulit, Karet, dan Plastik, Yogyakarta, Indonesia, pp 1-10 (2016).

23. Z. Gao, Z. Yu, C. Huang, L. Duan, G.H. Gao, Journal of Applied Polyme Science, 134, 11(2016), DOI: $10.1002 / A P P .44590$

24. C. M.Hassan, J. E. Stewart, and N.A. Peppas ,European Journal of Pharmaceutics and Biopharmaceutics, 49(2), 161(2000), DOI: 10.1016/S0939-6411(99)00056-9

25. C.Chang and L.Zhang, Carbohydrate Polymer, 84(1), 40(2011), DOI: 10.1016/j.carbpol.2010.12.023

26. N. Reddy and Y. Yang, Food Chemistry, 118(3), 702(2010), DOI: 10.1016/j.foodchem.2009.05.050 
RASĀYAN J. Chem.

Vol. 12 | No. 2 |554 - 564| April - June | 2019

27. A. H.Saputra,M. Hapsari, A. B. Pitaloka, P. P. D. K. Wulan. In SOMCHE 2014 and RSCE 2014 Conference, Selangor Darul Ehsan, Malaysia, Journal of Engineering Science and Technology, 10, 75(2015).

28. M.Sauer, D. Porro, D. Mattanovich, and P. Branduard, Trends Biotechnol, 26(2), 100 (2008), DOI: 10.1016/j.tibtech.2007.11.006

29. E.Menzel, Olsson, T. S. Plivelic, R. Andersson, C. Johansson et al, CarbohydPolym, 96, 270 (2013), DOI: $10.1016 /$ j.carbpol.2013.03.044

30. S. Denghani, S.V. Hosseini, and J.M. Regenstein, Food Chemistry, 240, 505 (2018), DOI: 10.1016/j.foodchem.2017.07.034

31. Kim, B.R., Yoo, J.-H., Jung, K.-S., Heu, S. G., \& Lee, S.-Y., Journal of Food Hygiene and Safety, 27, 449(2012).

32. J. Uranga, A.I. Puertas, A. Etxabide, M.T. Dueñas, P. Guerrero, K. de la Caba, Food Hydrocolloids, 86, 95(2019), DOI: 10.1016/j.foodhyd.2018.02.018

33. L.Golbaghi, M. Khamforoush, and T. Hatami, Carbohydrate Polymers, 174, 780 (2017), DOI: 10.1016/j.carbpol.2017.06.123

34. P.Rachtanapun, S. Luangkamin, K. Tanprasert, R. Suriyatem, Food Science and Technology, 48(1), 52 (2012), DOI: 10.1016/j.lwt.2012.02.029

35. R. W. Eyler, E. D. Klug, and F. Diephuis, Analytical Chemistry, 19, 24(1947),DOI: 10.1021/ac60001a007

36. M. P.Adinugraha, D.W. Marseno, and Hayadi, Carbohydrate Polymers, 62(2), 164(2005), DOI: 10.1016/j.carbpol.2005.07.019

37. T.H.Heinze, And K. Pfelifer, Macromolecular Materials and Engineering, 266, 37 (1999), DOI:10.1002/(SICI)1522-9505(19990501)266:1<37::AID-APMC37>3.0.CO;2-Z

38. E. Sjostrom, Wood Chemistry Fundamentals and Applications second edition, Academic Press, Inc, United States, p.204,216(1993).

39. Sutradhar, S. Chandra, M.M.R. Khan, M.M. Rahman and N.C. Dafadar, Journal of Physical Science, 26(2), 23(2015)

40. B.Soni, Hassan, E. B., \& Mahmoud, B. Carbohydrate Polymers, 134, 581(2015), DOI: $10.1016 /$ j.carbpol.2015.08.031

41. A.Salama, M. Neumann, C. Günter, and A. Taubert, Beilstein Journal of Nanotechnology, 5, 1553(2014), DOI: 10.3762/bjnano.5.167

42. P.Mario, D.W. Adinugrada, M. Haryadi, Carbohydr. Polym, 62(2), 164(2005), DOI: 10.1016/j.carbpol.2005.07.019

43. A.A.P.Mansur, F.G. de Carvalho, R.L. Mansur, S.M. Carvalho, L.C. de Oliveira, H.S. Mansur, Int. J. Biol. Macromol, 96, 675 (2017), DOI: 10.1016/j.ijbiomac.2016.12.078

44. R.M.Silverstein, G.C. Basser, and T.C. Masrill, Spectrometric Identification of Organic Compound, Fifth Edition, Jhon Wiley \& Sons, Inc, New York, p. 1(1991).

45. H.M.C.Azeredo, C. Kontou-Vrettou, G.K. Moates, N. Wellner, K. Cross, P.H.F. Pereira, K.W. Waldron, Food Hydrocoll, 50, 1(2015), DOI: 10.1016/j.foodhyd.2015.04.005

46. N.S.V.Capanema, A.A.P. Mansur, A.C. de Jesus, S.M. Carvalho, L.C. de Oliveira, and H.S. Mansur, International Journal of Biological Macromolecules, 106, 1218(2017), DOI: 10.1016/j.ijbiomac.2017.08.124

47. M. D.Harun-or-Rashid, M. D. Saifur Rahaman, Shariff Enamul Kabir, Mubarak A Khan, J. Appl. Polym., 133(2), 1(2016), DOI: 10.1002/APP.42870

48. E.Mani-López, H.S. Garcia, and A. López-Malo, J. Food Res., 45(2), 713(2012), DOI: 10.1016/j.foodres.2011.04.043

49. Y.J.Kong, B.K. Park, and D.H Oh, Korean J. Food Sci. Technol., 33(2), 178(2001).

50. S. Fardiaz, 1992. Mikrobiologi Pangan I. Gramedia Pustaka Utama, Jakarta.

[RJC-5126/2018] 